\title{
DEMOGRÁFIAI, GAZDASÁGI-TÁRSADALMI FOLYAMATOK ROMÁNIA VÁROSAIBAN 1948-TÓL NAPJAINKIG
}

\author{
(Demographic, Economic and Social Processes in the Romanian \\ Towns from 1948 till Nowadays)
}

\section{ELEKES TIBOR}

\begin{abstract}
Kulcsszavak:
iparositás urbanizáció népességgyarapodás dezurbanizáció népességfogyás

A II. világháború után elkezdödött, központilag irányitott eröteljes iparositás hatására 1948-1990 között Románia városi népessége $240 \%$-kal növekedett. Régiók, megyék és városok viszonylatában eltérō mértékü népességfogyást eredményezett az 1990 után elkezdödött gazdasági szerkezetátalakitás, a társadalmi változások.
\end{abstract}

\section{A II. világháborútól 1990-ig}

A II. világháború után új társadalmi-gazdasági korszak kezdődött Romániában. $\mathrm{Az}$ állam térszerkezete politikai korlátok között fejlödött, növekedett a belsô kapcsolatrendszer intenzitása és textúrája. Felerősödőtt a politika társadalmi-gazdasági folyamatokat befolyásoló szerepe. A kormányzat által irányított tervgazdálkodás az ország általános, gyorsütemú fejlỏdése mellett elsődleges feladatként kezelte a kevésbé fejlett térségek felzárkóztatását, a korábbi évtizedekbỏl örökölt gazdaságitársadalmi egyenlótlenségek felszámolását.

A korabeli ipartelepítés gyakorta figyelmen kívül hagyta a helyi adottságokat, a természeti környezet sajátosságait, az ipari hagyományokat, a létesített üzemek nem a helyi gazdasági-társadalmi élet szerves fejlődésének eredményeként jelentek meg.

Központilag irányították a településhálózat fejlesztését. Az állami nagyvállalatok elhelyezésének függvényében alakult a település-finanszírozás és az intézményfejlesztés.

Többnyire a korábban kialakult városhálózathoz, kisebb részt ebben az idöszakban létesített ipari-urbánus térségekhez kapcsolódnak az 1960-as évektől felerősödött intenzív iparosítás és a korabeli urbanizációs folyamatok, elsősorban a lakótelepi építkezések. A korabeli migrációs folyamatok a falu-város intra- és interregionális vándorlás.

Az 1980-as éveket a felerósödő központosítás, a „társadalmi homogenizáció”, a „gazdasági-energetikai függetlenedés” jellemezte.

Az 1990 előtti 4 évtized alatt Románia népessége 46\%-kal, a városi népesség 240\%-kal növekedett (1 táblázat). 


\section{TÁBLÁZAT}

Az összlakosság, a városi és a falusi népesség számának és arányának változása Romániában, 1948-2002 között (Changes in the Number and Rate of Total Population, Urban and Rural Population in Romania between 1948-2002)

\begin{tabular}{|c|c|c|c|c|c|}
\hline \multirow{2}{*}{$\begin{array}{l}\text { Év- } \\
\text { szám }\end{array}$} & \multirow{2}{*}{$\begin{array}{c}\text { Románia } \\
\text { összlakossága }\end{array}$} & \multicolumn{2}{|c|}{ Városi népesség } & \multicolumn{2}{|c|}{ Falusi népesség } \\
\hline & & $f o$ & $\%$ & $f^{\prime \prime}$ & $\%$ \\
\hline 1948 & 15872624 & 3713139 & 23,4 & 12159485 & 76,6 \\
\hline 1956 & 17489450 & 5474264 & 31,3 & 12015186 & 68,7 \\
\hline 1966 & 19103163 & 7305714 & 38,2 & 11797449 & 61,8 \\
\hline 1977 & 21559910 & 9395729 & 43,6 & 12164181 & 56,4 \\
\hline 1983 & 22553074 & 11054179 & 49,0 & 11498895 & 51,0 \\
\hline 1990 & 23206720 & 12608844 & 54,3 & 10597876 & 45,7 \\
\hline 1992 & 22810035 & 12391819 & 54,3 & 10418216 & 45,7 \\
\hline 2002 & 21698181 & 11436736 & 52,7 & 10261445 & 47,3 \\
\hline
\end{tabular}

Forrás: Népszámlálási adatok (1992; 2002); Statisztikai évkönyvek (1948; 1964; 1983; $1990 ; 1996 ; 2000)$.

A 2 milliósra növekedett Bukarest mellett a történelmi régióközpontok (Temesvár, Kolozsvár, Jászvásár, Konstanca és Craiova), valamint az elönyös földrajzi elhelyezkedésủ, közlekedési, kereskedelmi csomópontok (Brassó és Galac) erőteljes fejlesztése 300 ezres városok kialakulását eredményezte 1990-re. A megyeszékhelyek népességszáma 100 ezer, ritkábban 50 ezer fő fölé emelkedett. A városhálózat felét jelentő 25 ezer alatti kisvárosok szerényebb fejlődését, népességgyarapodását az ipar, bányászat, kisebb mértékben az idegenforgalom biztosította.

\section{0-töl napjainkig}

Az 1989. decemberi események után politikai, gazdasági, társadalmi átalakulás kezdődött el Romániában. Részben a korábbi évtizedekre jellemző erőteljesen központosított vezetéssel, elszigeteltséggel, bezártsággal magyarázható a piacgazdaságra történő lassúbb áttérés. Az 1970-es, 1980-as évek technikai színvonalán müködő ágazatok, a „ráfizetéses" bányák, kohászati, vegyipari létesítmények, az egy funkciós települések, övezetek leértékelődése jellegzetes társadalmi, környezeti és demográfiai problémákkal társult.

Megváltoztak az 1990 elött „,központilag irányított” demográfiai folyamatok. A korábbi évtizedekben folyamatosan gyarapodó népességszám csúcsértékét 1990-ben érte el. A természetes szaporulaton alapuló népességnövekményt 1992-től természetes fogyás (évente 10-55 ezer fö) váltotta fel. Ugyanakkor felerősödött a jobb megélhetés lehetősége reményében kivándorlók száma is. A kismértékủ bevándorlás (3-12 ezer évente) ellenére, 1990-2002 között Románia népessége 1,5 millióval $(6,5 \%$-kal) fogyott. 
Demográfiai, gazdasági-társadalmi folyamatok Románia városaiban 1948-tól napjainkig. Tér és Társadalom 22. évf. 2008/2. 185-201. p.

TÉT XXII. évf. 2008 『 2 Kitekintö

A kedvezőtlen demográfiai folyamatok térbeli sajátosságait, a 12 év népességváltozásának megyei értékeit az 1 . ábra összegzi.

\section{1. ÁBRA}

A romániai megyék népességszámának változása 1990-2002 között

(Changes in the Number of the Romanian Counties Population between 1990-2002)

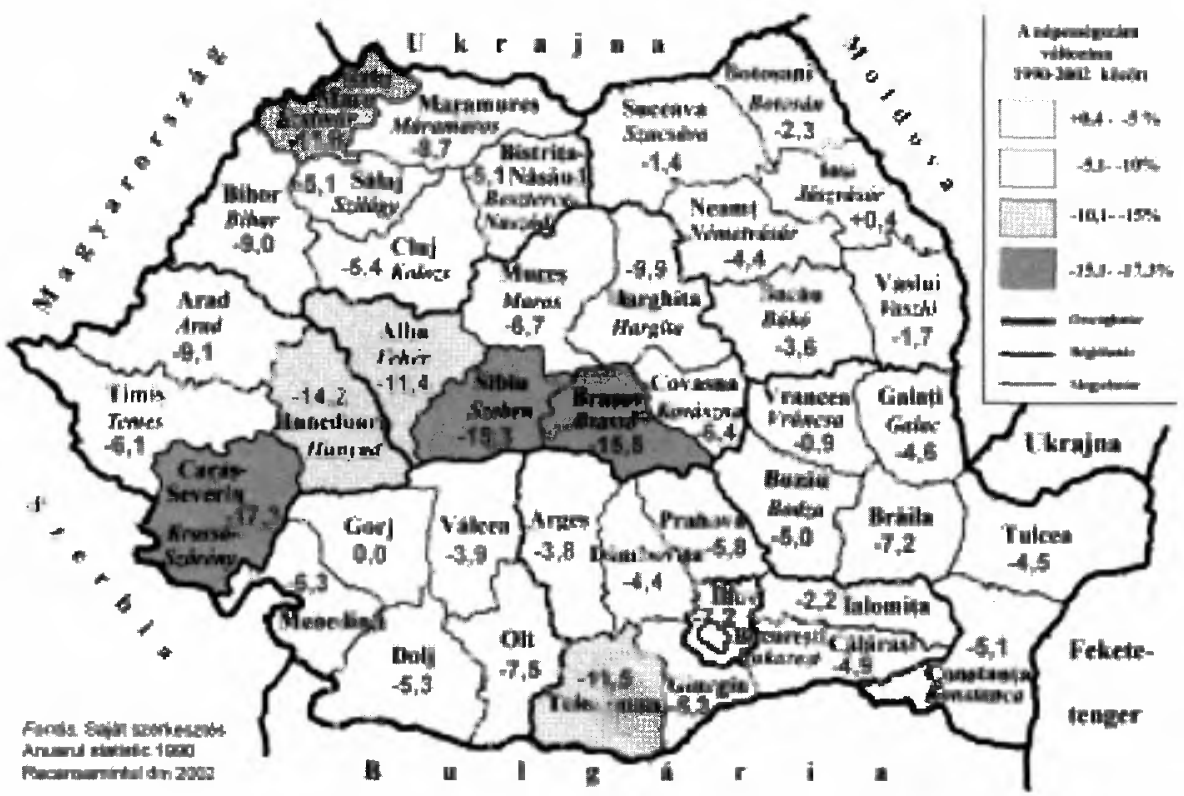

Forrás: Statisztikai évkönyv (1990) és népszámlálási (2002) adatok alapján saját szerkesztés.

A 20. század utolsó évtizedében a külföldi tỏke lassabban és kisebb mértékben érkezett Romániába, mint az Európai Unióhoz 2004. május elsején csatlakozott országokba. A befektetések fele Bukarestbe irányult, de jelentős célterület a nyugati határsáv, az Erdélyi-medence, a Fekete-tenger partja, valamint Havasalföld északi része. „Tőkeszegény” térségek Moldva és Kelet-Munténia.

Napjainkban a társadalmi, gazdasági, térszerkezeti változásokban felerősödhet az 1997-ben kialakított 8 régió szerepe. Ezért az alábbiakban a romániai városok népességszám változásait a régió - megye - nagy- és közepes városok viszonylatában, a jellegzetes gazdasági, társadalmi folyamatok függvényében ismerhetjük meg.

\section{Nyugati régió}

$\mathrm{Az}$ Arad, Temes, Krassó-Szörény és Hunyad megyét magában foglaló térséget nagyszámú város és országos viszonylatban nagy arányú városi népesség jellemzi. Az ipari hagyományokkal rendelkezö, több nemzetiségü és felekezetü, már a 19. században jelentős urbanizáltságú térség ma is Románia egyik legfejlettebb része. 
Temesvár, a Bánság (Temesköz) hagyományos gazdasági, művelődési, oktatási központja a II. világháború utáni 4 évtizedben megháromszorozta népességét. Az ipari fejlesztések a többszörösére emelték Arad (gépgyártás, vegyi-, fa-, textilipar), Resicabánya (vaskohászat, gépgyártás), Déva (energetika-, gépgyártó-, élelmiszerés textilipar), Vajdahunyad (a Petrozsényi-medencében bányászott szénre és a Ruszka-havasokban kitermelt vasércre telepített, később import nyersanyagot feldolgozó vaskohászat és gépgyártás), valamint a Petrozsényi-medence bányavárosainak népességét (2. táblázat). A kisvárosok fejlödését nagyobbrészt a bányászat és a gépgyártás biztosította.

A hagyományosan alacsony természetes szaporulatú régióban (a természetes fogyás Arad megyében 1978-tól, a másik három megyében az 1980-as évek második felétől kezdödött) a megnövekedett munkaeröigényt részben a négy megye községei, részben a távolabbi régiók (Moldva) fiatal lakossága biztosította.

1990 után elkezdődött a bányászat, kohászat, a gépgyártó- és a vegyipar jelentös részének leépülése. A 8 régió viszonylatában itt a legnagyobb mértékü a népességcsökkenés (1. ábra); okai a természetes fogyás (1998-ban -0,33\% a régió középértéke) az interregionális (részben visszavándorlás) és a kivándorlás. A nemzetközi migrációba az 1960-as években bekapcsolódó bánsági svábokat az 1990-es évek második felétöl románok, magyarok és más nemzetiségüek követték. A kis mértékü szuburbanizáció a nagyobb városokat érinti.

A gazdasági-társadalmi problémák fokozottabban jelentkeztek a bányavárosokban, a kohászati központokban és a gépgyártás napjainkra válságba sodródott ágazataiban.

1990-2002 között 27,7\%-kal fogyott Újmoldova bányaváros, 24\%-kal Resicabánya, 20\%-kal Vajdahunyad, 18,3\%-kal Karánsebes, 17,9\%-kal Zsombolya lakossága. A legkisebb mértékủ fogyás országos középérték $(9,3 \%)$ körüli (Temesvár 9,6\%).

\section{TÁBLÁZAT}

A lakosságszám változása a Nyugati régió 30 ezer fönél népesebb városaiban (ezer fö) (Changes in the Number of Inhabitants in Towns Populated by More than 30000 People of the West Region [one thousand person])

\begin{tabular}{lcrrrrrrr}
\hline & 1948 & 1964 & 1983 & 1990 & 1992 & 1996 & 2000 & 2002 \\
\hline ARAD & 87 & 115 & 184 & 203 & 190 & 185 & 183 & 172 \\
\hline TEMESVÁR & 112 & 152 & 303 & 351 & 334 & 332 & 330 & 318 \\
Lugos & 26 & 32 & 52 & 54 & 51 & 50 & 49 & 45 \\
\hline Resicabánya & 25 & 48 & 102 & 110 & 97 & 95 & 93 & 84 \\
Karánsebes & 10 & 18 & 31 & 35 & 32 & 31 & 31 & 28 \\
\hline Déva & 13 & 23 & 75 & 82 & 78 & 77 & 76 & 69 \\
Vajdahunyad & 7 & 59 & 87 & 90 & 81 & 80 & 78 & 71 \\
Petrozsény & 14 & 32 & 47 & 53 & 52 & 53 & 50 & 45 \\
Vulkán & 15 & 23 & 32 & 36 & 35 & 36 & 33 & 30 \\
Lupény & 21 & 33 & 31 & 33 & 33 & 33 & 31 & 31 \\
Petrilla & & 28 & 26 & 29 & 30 & 30 & 28 & 26 \\
\hline
\end{tabular}

A táblázatokban a városok megyénként szerepelnek, első helyen a megyeszékhely.

Forrás: Népszámlálási adatok (1992; 2002); Statisztikai évkönyvek (1948; 1964; 1983; $1990 ; 1996 ; 2000)$. 
Demográfiai, gazdasági-társadalmi folyamatok Románia városaiban 1948-tól napjainkig.

Tér és Társadalom 22. évf. 2008/2. 185-201. p.

Napjainkban is zajlik a ráfizetéses ágazatok leépítése (Petrozsényi-medence, Újmoldova). Folyamatban van az energetika- és a vegyipar átalakítása.

1990 után jelentős mennyiségü külföldi tőke érkezett Temes és Arad megyébe. Temesvár jól érzékelhető regionális felértékelődése mellett a tervezett dél-erdélyi autópálya Arad-Temesvár-Déva térségében hozhat gazdasági-társadalmi javulást. Magyarország EU-tagságával, valamint Románia csatlakozásával tovább erősödik a nyugati határvidék gazdasági szerepe. A régió halmozottan hátrányos térsége a Petrozsényi-medence. Krassó-Szörény megyében ,a gazdasági periféria jelleg” felerősödése tapasztalható.

\section{Északnyugati régió}

A Bihar, Kolozs, Szilágy, Szatmár, Máramaros és Beszterce-Naszód megye által képzett régió II. világháború utáni iparositása a nagy gazdasági-kereskedelmi központok (Kolozsvár, Nagyvárad), a közepes- és kisvárosok fejlesztését és az új ipari övezetek kialakítását jelentette. A megyeszékhelyek növekedése (2,5-7-szeres népesség gyarapodás), a városhálózat sürüsödése (pl. Máramaros megyében) jellemezte a tervgazdálkodás időszakát. Az „erősen urbanizált ipari övezetek” kialakulása (Kolozsvár-Torda-Aranyosgyéres, Nagybánya környéke) is erre az időszakra tevődik. Az ipar által uralt gazdasági szerkezet biztosította a korabeli városfejlödést.

1945 után e 6 megye az országos belső vándorlás egyik célterülete volt. Természetes szaporulata (1967-ben 1,81\%,1985-ben 0,49\%) országos középérték közeli, 1990-től azonban negatív az egyenlege. 1998-ban Kolozs, Bihar, Szatmár és Szilágy megyében $-0,1 \%-0,3 \%$-os volt az éves természetes fogyás. A határ menti megyék népességcsökkenését ( $I$. ábra) nagyobbrészt a régiók közti és a nemzetközi vándorlás okozza.

\section{TÁBLÁZAT}

A lakosságszám változása az Északnyugati régió 30 ezer fönél népesebb városaiban (ezer fö)

(Changes in the Number of Inhabitants inTowns Populated by More than 30000

People of the North-West Region [one thousand person])

\begin{tabular}{lcrrrrrrr}
\hline & 1948 & 1964 & 1983 & 1990 & 1992 & 1996 & 2000 & 2002 \\
\hline NAGYVÁRAD & 82 & 110 & 206 & 229 & 223 & 224 & 221 & 206 \\
\hline KOLOZSVÁR & 118 & 167 & 301 & 329 & 329 & 332 & 329 & 318 \\
Torda & 26 & 40 & 60 & 63 & 61 & 62 & 60 & 56 \\
Dés & 15 & 23 & 38 & 41 & 41 & 41 & 41 & 38 \\
Aranyosgyéres & & 15 & 27 & 30 & 29 & 30 & 30 & 27 \\
Zilah & 12 & 14 & 50 & 67 & 68 & 71 & 70 & 63 \\
SZATMÁRNÉMETI & 47 & 64 & 125 & 138 & 132 & 130 & 129 & 116 \\
\hline NAGYBÁNYA & 21 & 49 & 130 & 152 & 149 & 149 & 150 & 138 \\
Máramarossziget & 18 & 28 & 42 & 45 & 44 & 45 & 44 & 41 \\
Borsabánya & & 16 & 28 & 30 & 27 & 27 & 27 & 27 \\
Beszterce & 16 & 24 & 67 & 87 & 88 & 87 & 86 & 81 \\
\hline
\end{tabular}

Forrás: Népszámlálási adatok (1992; 2002); Statisztikai évkönyvek (1948; 1964; 1983; $1990 ; 1996 ; 2000$ ). 
1990-2002 között 20\%-kal csökkent Nagykároly, 17,7\%-kal Nagyszalonta, 16\%-kal Szatmárnémeti népessége. Nagyváradon és Nagybányán az országos átlag körüli érték jellemző $(-9,8 \%$, illetve $-9,5 \%)$. Zilahon, Besztercén és térségük kisvárosaiban a számbeli gyarapodást az 1990-es évek közepén a fogyás váltotta fel (3. táblázat).

Kolozsvár, Erdély hagyományos gazdasági, közlekedési, müvelődési, oktatási centruma napjainkban is regionális vonzásközpont. Sokat vesztett korábbi gazdasági szerepéből a közeli Torda és Aranyosgyéres. A szuburbanizáció Kolozsvár, Nagyvárad és Nagybánya övezetében jelentkezik.

A határ menti térségek felértékelődésével, jelentös bel- és külfơldi tỏkebefektetésekkel Nagyvárad részben ellensúlyozza Kolozsvár régióközponti szerepét. A tervezett Bukarest-Budapest észak-erdélyi autópálya a két nagyvárost, valamint Zilahot és Tordát is érinti. Felértékelödőben van a régió idegenforgalmi központjainak, térségeinek szerepe. Hátrányos térségek Nagybánya és vonzáskörzete (bányabezárások, környezeti problémák), valamint a Máramarosi-medence kisvárosai. A leghátrányosabb demográfiai mutatók Szatmár megyét jellemzik.

\section{Központi régió}

A románok, magyarok és korábban németek által lakott hat délkelet-erdélyi megyére terjedő régió (Fehér, Maros, Hargita, Kovászna, Brassó és Szeben). Az ország egyik legsürübb városhálózatú térségében a hagyományos nagy ipari övezetek (gépgyártó-, textil- és élelmiszeripar) Brassó és vonzáskörzete, Nagyszeben, valamint Marosvásárhely.

A II. világháború utáni országos fejlesztési terv egyik kiemelt városa, az ország földrajzi és közlekedési központjában elhelyezkedö Brassó. 4 évtized alatt gép(traktor, teherautó, csapágy), fa-, vegyi-, készruha és élelmiszeripari gyárakkal gyarapodott. 1990-ben, Románia második legnépesebb városában a gépgyártás biztosította az ipari termelés több mint felét. Változatosabb gazdasági szerkezet jellemzi Nagyszebent és Marosvásárhelyt. A régió további három megyeszékhelye (Gyulafehérvár, Sepsiszentgyörgy és Csíkszereda), valamint az erösen urbanizált NagyKüküllö völgye a hagyományos fa-, textil- és élelmiszeripar mellett gép-, vegyi- és épitöiparral bỏvült. A 19-20. században létesített idegenforgalmi központokat gyógy- és üdülötelepekké fejlesztették, városokká nyilvánították (Szováta, Borszék, Tusnád, Kovászna, Predeál, Vízakna stb.).

Az iparosítás időszakában a régió természetes szaporulata országos középérték körüli volt. A kisvárosok munkaerö igényét nagyobbrészt a környező rurális térségek, a nagyvárosok esetében tőbbnyire a szomszédos moldvai megyék biztosították.

1990 után a régió természetes szaporulata $0,2 \%-0,4 \%$ között váltakozott, a népesség számbeli alakulását a vándorlás határozta meg. A 20. század utolsó évtizedében a régió drasztikus népesség-csökkenését több folyamat idézte eló. Az elavult ipari technológia alkalmazása, a „ráfizetéses” ágazatok leépítésének szükségszerüsége, a korábbi piacok elvesztése gyárbezárásokat eredményezett. Az 1990 utáni első években felerősödött a szászok, később a magyarok és románok kivándorlása. A mun- 
Demográfiai, gazdasági-társadalmi folyamatok Románia városaiban 1948-tól napjainkig. Tér és Társadalom 22. évf. 2008/2. 185-201. p.

kahely elvesztése, a megélhetési feltételek hiánya intra- és interregionális vándorlást (részben „visszavándorlást”) idézett elö. 1990-2002 között Szeben és Brassó megye népességcsökkenése az országos átlag $(6,5 \%) 2$ és félszerese volt (1. ábra).

\section{TÁBLÁZAT}

A lakosságszám változása a Központi régió 30 ezer fönél népesebb városaiban (ezer fö)

(Changes in the Number of Inhabitants in Towns Populated by More than 30000 People of the Central Region [one thousand person])

\begin{tabular}{|c|c|c|c|c|c|c|c|c|}
\hline & 1948 & 1964 & 1983 & 1990 & 1992 & 1996 & 2000 & 2002 \\
\hline Gyulafehérvár & 14 & 20 & 59 & 73 & 71 & 72 & 72 & 66 \\
\hline Kudzsir & & 13 & 30 & 34 & 32 & 31 & 30 & 26 \\
\hline Szászsebes & 10 & 13 & 30 & 31 & 30 & 30 & 29 & 28 \\
\hline Nagyenyed & 10 & 16 & 28 & 30 & 32 & 29 & 29 & 29 \\
\hline $\begin{array}{l}\text { MAROSVÁ- } \\
\text { SÁRHELY }\end{array}$ & 47 & 76 & 155 & 172 & 164 & 166 & 163 & 150 \\
\hline Szászrégen & 10 & 22 & 35 & 39 & 39 & 39 & 39 & 36 \\
\hline Segesvár & 18 & 24 & 36 & 39 & 36 & 36 & 36 & 32 \\
\hline Dícsőszentmárton & 8 & 19 & 29 & 31 & 31 & 30 & 30 & 27 \\
\hline Csíkszereda & 6 & 14 & 44 & 48 & 46 & 47 & 46 & 42 \\
\hline Székelyudvarhely & 10 & 16 & 38 & 41 & 40 & 39 & 39 & 37 \\
\hline Sepsiszentgyörgy & 14 & 20 & 62 & 73 & 68 & 67 & 66 & 62 \\
\hline BRASSÓ & 83 & 137 & 331 & 364 & 323 & 320 & 310 & 284 \\
\hline Fogaras & 9 & 22 & 40 & 46 & 45 & 45 & 44 & 36 \\
\hline Szecseleváros & & 21 & 34 & 34 & 30 & 30 & 30 & 30 \\
\hline NAGYSZEBEN & 60 & 103 & 172 & 188 & 167 & 169 & 168 & 155 \\
\hline Medgyes & 23 & 42 & 71 & 73 & 64 & 63 & 62 & 55 \\
\hline
\end{tabular}

Forrás: Népszámlálási adatok (1992; 2002); Statisztikai évkönyvek (1948; 1964; 1983; $1990 ; 1996 ; 2000)$.

A Székelyföldet magában foglaló Kovászna, Hargita és Maros megyében országos középérték körüli a fogyás. (A 12 éves időszakban Hargita megye 35 ezer fős fogyásából 7 ezer fôvel Balánbánya ,részesült".)

1990-2002 között a városok lélekszámfogyása is meghaladta az országos középértéket (9,3\%): Brassóban 22\% (80 ezer fó), Nagyszebenben 17,7\%, Medgyesen $24,5 \%$, Marosvásárhelyen 13,3\%, Sepsiszentgyörgyön 15,4\%, Csíkszeredán 13,6\%, Székelyudvarhelyen 10,9\%, Gyulafehérváron $9,6 \%$ volt a csökkenés (4. táblázat). Országos viszonylatban a legnagyobb veszteség Balánbányát érte (47\%).

Várhatóan még évekig eltart a városok, elsősorban Brassó, Nagyszeben és Marosvásárhely gazdaságszerkezetének átalakulása. Az infrastrukturális beruházások, a repülöterek (a 3 nagyváros versengése) és az autópályák vonzóbbá tehetik e térséget a tőke számára.

A válságtérségek (pl. Balánbánya) és a környezetszennyezés (pl. Kiskapus) felszámolása átfogó, több évtizedig tartó munkát igényel. Az idegenforgalom terén 
elkezdödött folyamatok a fejlődés kiindulópontjai lehetnek a kiterjedt erdőségekkel, jelentős földgáz- és óriási só tartalékokkal rendelkező régióban.

\section{Északkeleti régió}

Moldva hat északi és központi megyéje (Suceava, Botoşani, Neamț, Bákó, Jászvásár és Vaslui) Románia legszegényebb térsége. Hagyományos kereskedelmi, ipari és müvelödési központja Jászvásár.

Az erőltetett gazdasági fejlesztés 4 évtizedében a megyeszékhelyek, a 8 közepes nagyságú város, valamint az Elökárpátokban az Aranyos-Beszterce és a Tatros völgyében kialakított bányászati, vegyipari térségek többszörös népességgyarapodása a jellemzö. A városok vonzáskörzetéból érkező fiatal népesség megélhetését az ủj ipari létesítmények és a lakótelepek biztosították. Az 1990 előtti évtizedekben e kevésbé urbanizált régióban a falu város migráció több százezer ember lakhelyváltoztatását jelentette.

Hasonló mértékủ volt az interregionális vándorlás is. 1948-1990 között a moldvai megyék természetes szaporulata az országos középérték kétszerese, a fiatal népesség egy része az ország nyugati, középsó és délkeleti megyéibe települt. A népesség kibocsátó szerep 1990-ig interregionális, 2000 után nemzetközi jellegü.

1990-2002 között a népességfogyás az országos érték fele (1. ábra). Ugyanakkor a Jászvásári az egyetlen megye, melyet növekedés jellemez. Természetes szaporulata pozitív (pl. 1998-ban országos viszonylatban a legmagasabb: 0,39\%,), a Moldvai köztársaságból érkező betelepülök egy részének lakhelye. Jászvásár, a térség regionális központja, ma Románia második legnagyobb városa.

Az ország középsö és nyugati részével ellentétben, az enyhén csökkenő népességü Jászvásár és a hegyvidéki kisvárosok kivételével, a városok népességgyarapodását jelzik a statisztikai évkönyvek az 1990-es évek második feléig. Az 1992-es és 2002-es népszámlálások tükrében a régió északi városaiban 5-10\%-os, a déliekben 10-15\%-os a fogyás: Bákó 14,2\%-ot, Vaslui 12,8\%-ot, Bârlad 10,8\%-ot veszített népességéből (5. táblázat).

A kismértékü természetes szaporulat felerösödő város-falu irányú vándorlással társul. Az utóbbi években moldvai idénymunkások százezreit regisztrálták Olaszországban és Spanyolországban. A népmozgás gazdasági okaira mutat rá az átalakuló iparszerkezet is. 2003-ban a 6 megye kivitelének több mint fele ruhaipari termék. Botosani 78\%, Vaslui 65\%, Jászvásár 174 millió eurós exportjából 52\% a néhány éve megerősödött, nyugat-európai cégek által múködtetett textilipar részesedése. Egyelőre nem tervezik az ásványi nyersanyagokban szegény területet átszelő autópálya építését, a Moldvából déli és nyugati irányba haladó közlekedési vonalak bövítését. Az országba érkezett tőke töredéke került ebbe a régióba. 
Demográfiai, gazdasági-társadalmi folyamatok Románia városaiban 1948-tól napjainkig.

Tér és Társadalom 22. évf. 2008/2. 185-201. p.

\section{TÁBLÁZAT}

A lakosságszám változása az Északkeleti régió

30 ezer fönél népesebb városaiban (ezer fö)

(Changes in the Number of Inhabitants in Towns Populated by More than 30000

People of the North-East Region [one thousand person])

\begin{tabular}{lcrrrrrrr}
\hline & 1948 & 1964 & 1983 & 1990 & 1992 & 1996 & 2000 & 2002 \\
\hline SUCEAVA & 10 & 26 & 85 & 108 & 114 & 118 & 118 & 106 \\
Fălticeni & 11 & 17 & 26 & 31 & 33 & 33 & 33 & 30 \\
Rădăuţi & 15 & 19 & 27 & 31 & 31 & 32 & 32 & 28 \\
\hline BOTOŞANI & 29 & 32 & 95 & 124 & 126 & 129 & 127 & 115 \\
Dorohoi & 15 & 15 & 27 & 33 & 34 & 35 & 35 & 31 \\
\hline PIATRA & 26 & 39 & 103 & 118 & 123 & 126 & 124 & 105 \\
NEAMT & & & & & & & & \\
Roman & 24 & 35 & 68 & 79 & 80 & 82 & 81 & 69 \\
\hline BÁKÓ & 34 & 65 & 166 & 197 & 205 & 209 & 208 & 176 \\
Oneşti & & 26 & 49 & 58 & 59 & 61 & 60 & 52 \\
\hline JÁSZVÁSÁR & 94 & 124 & 306 & 346 & 344 & 347 & 346 & 322 \\
Paşcani & 11 & 18 & 33 & 41 & 45 & 46 & 46 & 42 \\
\hline Vaslui & 14 & 17 & 58 & 75 & 81 & 80 & 78 & 70 \\
Bârlad & 24 & 38 & 66 & 77 & 78 & 79 & 78 & 70 \\
Huși & 17 & 20 & 27 & 32 & 33 & 33 & 33 & 30 \\
\hline
\end{tabular}

Forrás: Népszámlálási adatok (1992; 2002); Statisztikai évkönyvek (1948; 1964; 1983; $1990 ; 1996 ; 2000)$.

\section{Délkeleti régió}

Dél-Moldva, Északkelet-Munténia és Dobrudzsa két-két megyéjéből (Vrancea, Galac, Buzău, Brăila, Tulcea és Konstanca megyék) alakították ki. Nagyvárosai, Konstanca, Galac és Brăila jelentös tengeri és dunai kikötők. Nagy a várossürüség Konstanca megyében. A régió hagyományos gazdasági ágazatai a mezógazdaság (gabona, zöldség, gyümölcs, Vrancea dombvidékein a szőlötermesztés), a vízi és szárazfỏldi szállítás és a kereskedelem.

A korábbi évszázadok gazdasági örökségére alapozó hajógyártás, élelmiszer- és textilipar mellé az 1950-es évektöl vaskohászat (Galac, Călăraşi), vegyipar (Năvodari, Slobozia), gépgyártás (Brăila, Buzău, Galac), energetika- (Cernavoda-i atomerömú) és építöipar telepedett.

1948-1990 között e 6 megyében az országos középérték fölötti volt a természetes szaporulat (pl. Galac megyében 2,39\% 1967-ben, 1,06\% 1981-ben). A közép- és észak-moldvai megyékhez hasonlóan Vrancea és Galac népesség-kibocsátó, a két dobrudzsai megye munkaerő befogadó térség.

A nagyvárosok „versengésében” az 1970-es évek elején az ország keleti kapuja, Konstanca és Románia legnagyobb dunai kikötője, Galac népességnövekménye meghaladta Brăila gyarapodását. 
1990-2002 között a természetes fogyás, az interregionális migráció és az 1990-es évek második felétöl felerősödő kivándorlás Vrancea megyében $-0,9 \%$, Brăila megyében az országos középértéket meghaladó, a régió többi 4 megyéjében a romániai középérték alatti népességfogyást eredményezett. Az 1990-es évek második felétől ez a folyamat jellemzi a térség városait. A természetes fogyás, az elvándorlás és a szuburbanizáció egy évtized alatt 12,6\%-kal csökkentették Konstanca lakosságát, Brăila vesztesége 12,5\%, Galacé 8,4\%, Buzău-é 10,1\%. A tengerparti üdülővárosok kivételével hasonló demográfiai folyamatok jellemzik a közepes- és kisvárosokat is (Sulina fogyása 19\%, Medgidia-é 11\%).

Országos viszonylatban, a napjainkban is enyhén növekvő egyetlen 100 ezres város Vrancea megye székhelye, a történelmi Moldva és Havasalföld határán települt Focşani (6. táblázat).

Az aktív lakosság kisebb részét foglalkoztatják a sikeresen privatizált ipari létesítményekben (pl. a Năvodari-i vegyipari üzem az országos átlagkereset 2,5-szeresét fizeti alkalmazottainak). Az új készruha-, cipö- és élelmiszeripari üzemek nagyobbrészt női munkaerőt foglalkoztatnak (1996-ban egy készruhagyár müködött Vrancea megyében, 2003-ban 50 ezer alkalmazottja volt a megye textiliparának). Ebból a térségből származik az Európa fejlettebb részébe érkező román idénymunkások jelentős része.

\section{TÁBLÁZAT}

A lakosságszám változása a Délkeleti régió

30 ezer fönél népesebb városaiban (ezer fö)

(Changes in the Number of Inhabitants in Towns Populated by More than 30000

People of the South-East Region [one thousand person])

\begin{tabular}{lcrrrrrrr}
\hline & 1948 & 1964 & 1983 & 1990 & 1992 & 1996 & 2000 & 2002 \\
\hline FOCŞANI & 28 & 32 & 77 & 99 & 101 & 100 & 97 & 103 \\
\hline GALAC & 80 & 113 & 285 & 326 & 326 & 328 & 327 & 298 \\
Tecuci & 20 & 28 & 42 & 47 & 47 & 47 & 46 & 42 \\
\hline BUZĂU & 43 & 55 & 127 & 148 & 148 & 149 & 146 & 133 \\
Râmnicu Sărat & 19 & 22 & 34 & 40 & 41 & 42 & 41 & 39 \\
\hline BRĂlLA & 95 & 122 & 225 & 248 & 234 & 235 & 231 & 217 \\
\hline Tulcea & 22 & 31 & 79 & 95 & 98 & 97 & 95 & 93 \\
\hline KONSTANCA & 79 & 121 & 316 & 355 & 351 & 347 & 337 & 311 \\
Medgidia & 7 & 25 & 47 & 49 & 47 & 47 & 46 & 44 \\
Mangalia & 5 & 7 & 37 & 42 & 44 & 44 & 44 & 40 \\
Năvodari & & & 18 & 29 & 32 & 34 & 36 & 32 \\
\hline
\end{tabular}

Forrás: Népszámlálási adatok (1992; 2002); Statisztikai évkönyvek (1948; 1964; 1983; $1990 ; 1996 ; 2000)$.

Dobrudzsa hagyományos régióközpontja Konstanca. A Román-Alföld keleti részén a központi szerepkörért napjainkban Galac és Brăila verseng. A fejlődő vízi-, vasút- és közútvonalak érintik a régió jelentősebb városait. Ismét felerösödhet a tengerpart idegenforgalma. 


\section{Déli régió}

Hét megye (Prahova, Dâmbovița, Argeș, Teleorman, Giurgiu, Călăraşi és Ialomiţa) osztozik a Déli-Kárpátoktól a Dunáig terjedö, nagy településsürủségú és erős urbanizáltságú Közép-Munténia régión.

A síkság, domb- és hegyvidék jellegzetes gazdálkodási formáihoz kapcsolódó ágazatok (élelmiszer-, textil- és faipar) mellett már az 1930-as évektöl meghatározó a só, a kőolaj, később a szén gazdasági értékesítése. A II. világháború utáni vegyipar országos központjai Ploieşti, Piteşti, Brazi, Câmpina. Itt kezdődött a romániai személygépkocsi- (Piteşti) és a terepjárógyártás (Câmpulung). A Duna menti és az alföldi városokban a hajózás és az élelmiszergyártás vegyi- és gépiparral társul.

Országos viszonylatban nagyon magas a városok száma és népessége, valamint az iparosítás mértéke a Ploieşti székhelyủ Prahova és a Piteşti központú Argeş megyében. A régió falvaiból származik a 4 évtized alatt többszörösére növekedett városok fiataljainak egy része (7. táblázat). Ebben az időszakban a föváros növekvő munkaerőigényét nagyobbrészt a régió déli, Duna-menti megyéinek fiataljai biztosították. A régió északi és keleti részének, az országos középérték feletti természetes szaporulatát Teleorman és Giurgiu 1980-as évek végétől elkezdődött fogyása ellensúlyozza.

7. TÁBLÁZAT

A lakosságszám változása a Déli régió 30 ezer fönél népesebb városaiban (ezer fö) (Changes in the Number of Inhabitants in Towns Populated by More than 30000 People of the South Region [one thousand person])

\begin{tabular}{lcrrrrrrr}
\hline & 1948 & 1964 & 1983 & 1990 & 1992 & 1996 & 2000 & 2002 \\
\hline PLOIEŞTI & 96 & 134 & 230 & 259 & 253 & 254 & 249 & 232 \\
Câmpina & 17 & 21 & 37 & 40 & 42 & 41 & 40 & 39 \\
Târgoviște & 26 & 28 & 82 & 101 & 98 & 99 & 98 & 89 \\
\hline PITEŞT & 29 & 51 & 150 & 175 & 179 & 186 & 186 & 169 \\
$\begin{array}{l}\text { Câmpulung } \\
\text { Mioveni }\end{array}$ & 18 & 23 & 40 & 43 & 44 & 44 & 43 & 38 \\
Curtea de & & & & & 34 & 35 & 36 & 36 \\
Argeş & 9 & 15 & 28 & 33 & 36 & 36 & 34 & 33 \\
\hline Alexandria & 18 & 22 & 48 & 59 & 58 & 59 & 57 & 51 \\
Roşiori de & 15 & 20 & 33 & 37 & 38 & 37 & 36 & 32 \\
Vede & & & & & & & & \\
Turnu & 11 & 20 & 33 & 36 & 37 & 36 & 35 & 30 \\
Măgurele & 30 & 35 & 63 & 72 & 74 & 74 & 72 & 70 \\
Giurgiu & 24 & 30 & 63 & 76 & 77 & 78 & 77 & 70 \\
\hline Călăraşi & 10 & 17 & 28 & 33 & 32 & 32 & 31 & 27 \\
Oltenița & 8 & 11 & 42 & 52 & 56 & 57 & 55 & 53 \\
\hline Slobozia & 12 & 19 & 30 & 34 & 35 & 36 & 37 & 33 \\
Fetești & & 19 & & & & \\
\hline
\end{tabular}

Forrás: Népszámlálási adatok (1992; 2002); Statisztikai évkőnyvek (1948; 1964; 1983; 1990; 1996; 2000). 
1990-2002 között, Teleorman megye kivételével, enyhén fogyó népességü térség (1. ábra). Az északi és keleti megyék országos középérték körüli természetes fogyását enyhe bevándorlás ellensúlyozza (a jól müködő ipar vonzása, Bukarest szuburbanizációs folyamatai). Teleorman és Giurgiu megyében az 1980-as évek végén kezdödött természetes fogyás mértéke 1998-ban romániai viszonylatban a legnagyobb volt, az országos középérték $(-0,15 \%)$ többszöröse $(-0,73 \%$, illetve $-0,6 \%)$.

$\mathrm{Az}$ országos átlagnál kisebb az északi megyék nagy- és közepes városainak népességfogyása. A Prahova-völgye ipari-idegenforgalmi kisvárosaiban -3\%--21\% közötti a fogyás. A sikeres gépkocsi gyáráról ismert Mioveni lakossága 1992-2002 között 5,8\%-kal növekedett. A déli megyék városaiban -10\%--18\%-os a fogyás, kivétel a felértékelödött legnagyobb déli határátkelö, Giurgiu (-6,2\%) (7. táblázat).

Eltérö fejlődési irány körvonalazódik a régió északi és déli részében. A változatos domborzatú, kőolaj, szén, só kitermelő és feldolgozó északi 3 megye erőssége a vegyipar, a gépgyártás- és a faipar. A fövárosból induló két országos jelentőségü vasútvonal és részben megépített autópálya áthalad Ploieşti, illetve Piteşti városokon. Tőkevonzó tényezô a Petrom privatizációja és a kőolaj feldolgozás modernizálása. Felértékelödőben a Ialomiţa és Călărași megyéket átszelö BukarestKonstanca vasút, müút és autópálya gazdaságélénkító szerepe.

A leépült iparú, agrár-élelmiszerfeldolgozó déli megyékben a drasztikus természetes fogyás okozta veszteséget a fiatalok nyugat-európai ideiglenes munkavállalása vagy elvándorlása fokozza. A régió fejlödését meghatározó központok Bukarest, Ploieşti, Piteşti és Giurgiu.

\section{Délnyugati régió}

A változatos domborzatú régió öt megyéje (Vâlcea, Gorj, Dolj, Mehedinți és Olt) a síkságtól a hegyvidékig terjed. Kevés a város, az urbánus népesség nagyobb része a megyeszékhelyeken él. A történelmi Olténia központja Craiova.

Az iparositás a megyeszékhelyek népesség gyarapodását eredményezte (8. táblázat). A gépgyártás központjait Craiovára és vonzáskörzetébe helyezték. Râmnicu Vâlcea vegyipari, Târgu Jiu és Turnu Severin faipari üzemekkel bővült. Olténiát az ország egyik legfontosabb energetikai térségévé tették a Vaskapui vízierőmủvek és az észak-olténiai lignit hasznosítására, Craiova mellett épített hőerőmúvek.

Országos középérték körüli a természetes szaporulat az 1990 elötti évtizedekben, a rurális térségek biztosították a városok népesség gyarapodását. 1990-2002 között fogyásba váltott a korábbi természetes szaporulat. 12 év alatt Gorj lakosságszáma nem változott, a déli, Duna menti megyék népességcsökkenése országos középérték körüli. 1990-1992 között a régió városait a számbeli gyarapodás, 1992 után 5-10\%-os fogyás jellemezte. 


\section{TÁBLÁZAT}

A lakosságszám változása a Délnyugati régió

30 ezer fönél népesebb városaiban (ezer fö)

(Changes in the Number of Inhabitants in Towns Populated by More than 30000 People of the South-West Region [one thousand person])

\begin{tabular}{lcccccccc}
\hline & 1948 & 1964 & 1983 & 1990 & 1992 & 1996 & 2000 & 2002 \\
\hline RÂMNICU & 17 & 23 & 87 & 107 & 114 & 119 & 119 & 108 \\
$\begin{array}{l}\text { VĂLCEA } \\
\text { Târgu Jiu }\end{array}$ & 18 & 26 & 81 & 93 & 98 & 98 & 97 & 97 \\
$\begin{array}{l}\text { DROBETA- } \\
\text { TURNU }\end{array}$ & 31 & 37 & 92 & 107 & 115 & 118 & 116 & 104 \\
$\begin{array}{l}\text { SEVERIN } \\
\text { CRAIOVA }\end{array}$ & 85 & 122 & 260 & 317 & 304 & 311 & 312 & 303 \\
\hline Slatina & 13 & 15 & 67 & 88 & 85 & 87 & 86 & 79 \\
Caracal & 18 & 20 & 34 & 40 & 39 & 39 & 39 & 35 \\
\hline
\end{tabular}

Forrás: Népszámlálási adatok (1992; 2002); Statisztikai évkönyvek (1948; 1964; 1983; $1990 ; 1996 ; 2000)$.

A következő évekre tervezett változások átalakítják a régió bányászatát és energetikai ágazatát. Bányaleállitásokat Gorj megyében, hőerőművek bezárását Dolj megyében terveznek. Ugyanakkor Vâlcea vegyiparának, Mehedinți megye energetikaés faiparának megerősödése várható. A közeljövőben nem épül autópálya a korábbi évtizedekben fejlett vasút- és közúthálózattal ellátott térségben.

\section{Bukarest régió}

A Román-Alföldön található a fővváros és a körülötte kialakított Ilfov körzet. A rohamos iparosítás (húzóágazatok a fémfeldolgozás és a gépipar) megerősítette korábbi vezető gazdasági-, közigazgatási, oktatási, mủvelődési szerepét. A természetes szaporulat (1967-ben 1,55\%, 1985-ben 0,19\%) az iparosítás évtizedeiben elmaradt az országos középérték (1967-ben 1,81\%, 1985-ben 0,49\%) mögött. A közel 1 milliós vándorlási pozitívumot a fơváros körüli megyék és a hagyományos népesség kibocsátó térségek biztosították.

1990 után a természetes fogyás az országos középérték kétszerese, csökken a fövárosba költözők száma (9. táblázat). Az országba érkezett külföldi töke fele Bukarestbe telepedett, az országban alapított cégek jelentős részének a fövárosban is van székhelye. A tervezett autópálya-hálózat Bukarest központú.

\section{TÁBLÁZAT}

A lakosságszám változása Bukarest régióban (ezer fö)

(Changes in the Number of Bucureşti Region Inhabitants [one thousand person])

\begin{tabular}{lllllllll}
\hline & 1948 & 1964 & 1983 & 1990 & 1992 & 1996 & 2000 & 2002 \\
\hline BUKAREST & 1041 & 1240 & 1995 & 2128 & 2068 & 2037 & 2009 & 1922 \\
\hline
\end{tabular}

Forrás: Népszámlálási adatok (1992; 2002); Statisztikai évkönyvek (1948; 1964; 1983; 1990; 1996; 2000). 


\section{Összegzés}

A II. világháború utáni 4 évtizedben, a tervgazdaság keretében végrehajtott erőteljes iparosítás a városi lakosság $240 \%$-os növekedését eredményezte. A természetes szaporulat, a falu-város intra- és interregionális vándorlás eltérően érintette a megyéket, városokat. 1945-1990 között a gazdasági és demográfiai tényezők jellegzetes belső vándorlási folyamatokat indítottak el. A magas természetes szaporulatủ moldvai megyék népesség kibocsátó, a bánsági, partiumi, erdélyi és dobrudzsai megyék befogadó térségek, a dél-munténiai kivándorlás Bukarestbe és az északmunténiai városokba irányult.

Nagy várossürủség jellemzi az eröteljesen iparosított Prahova, Hunyad, Konstanca, Brassó, Argeş megyét. 45 év alatt több kisváros népessége 10-12-szeresre növekedett. A városhálózat gerincét a főváros, a 300 ezer fönél népesebb „regionális központok" és az általában 100 ezer fónél nagyobb megyeszékhelyek képezik. Az aránylag kevés 25-100 ezer fö közti népességü település és a nagyszámú kisváros többnyire az ipari övezetekben található.

1990-től a korábbi központosított gazdasági, társadalmi folyamatokat a demokratizálódás, a piacgazdaság és a jogállam kiépítésének folyamata váltotta fel. A csökkenő természetes szaporulat (1992-tól fogyás), az interregionális vándorlás (részben vissza-vándorlás) és a nemzetközi migráció 1990-2002 között Románia népességének 1,5 milliós fogyását eredményezte. 2002-ben az összlakosság 40,8\%-a aktív ( 8,85 millió fö, melynek 55,5\%-a városi, 44,5\%-a falusi), a fiatal korosztály az össznépesség 29,4\%-a (a diákokkal és egyetemi hallgatókkal 3,76 millió fö), a nyugdijasok aránya 39,5\% (5 millió fó).

Az 1990-es évek első felében a városi népességszám változását térben eltérö folyamatok alakították. A dél-erdélyi, bánsági, román-alföldi városokban és Bukarestben fogyott, Moldvában, Észak-Munténiában és számos gyógyüdülö-, fürdővárosban gyarapodott a lakosság. A Kárpátokban és az Erdélyi-középhegységben elkezdődött az Alpokra is jellemzö népességcsökkenés (2. ábra).

Az 1990-es évek második felétỏl általánossá válik a fogyás (3. ábra). 1990-2002 között nagyobb a veszteség Dél-Erdélyben, a Bánságban, a Partiumban, a RománAlföldön, Közép-Moldvában és az egyfunkciós bányász, kohász kisvárosokban.

Napjainkban a bányászat és az energetikai ipar átszervezése (2007-ig a 129 erómübỏl 87 marad üzemben) negatív, a vegyipar magánosítása pozitív hatást gyakorolhat a társadalmi folyamatokra. A külföldi tökebefektetések (2003-ban 1,57 milliárd USD, 2004-ben 40\%-kal nagyobb összeg) és a nemzetgazdaság fejlödése csökkentheti a társadalmi problémákat, a vándorlás mértékét.

Csökkentheti a kivándorlást az új munkahelyek létesítése (2002-ben a munkanélküliek összlétszáma 1040 098, a munkaképes lakosság 11,7\%-a; ebböl 60,5\% városon, $39,5 \%$ falun élt), a bérek növekedése is (2000-ben a havi átlagkereset 100 USD, 2003-ban 140 USD). A textil- és cipőipar által „uralt” térségekben a gyárak „keletebbre telepítése" újabb foglalkoztatási problémákat eredményezhet néhány év múlva. 


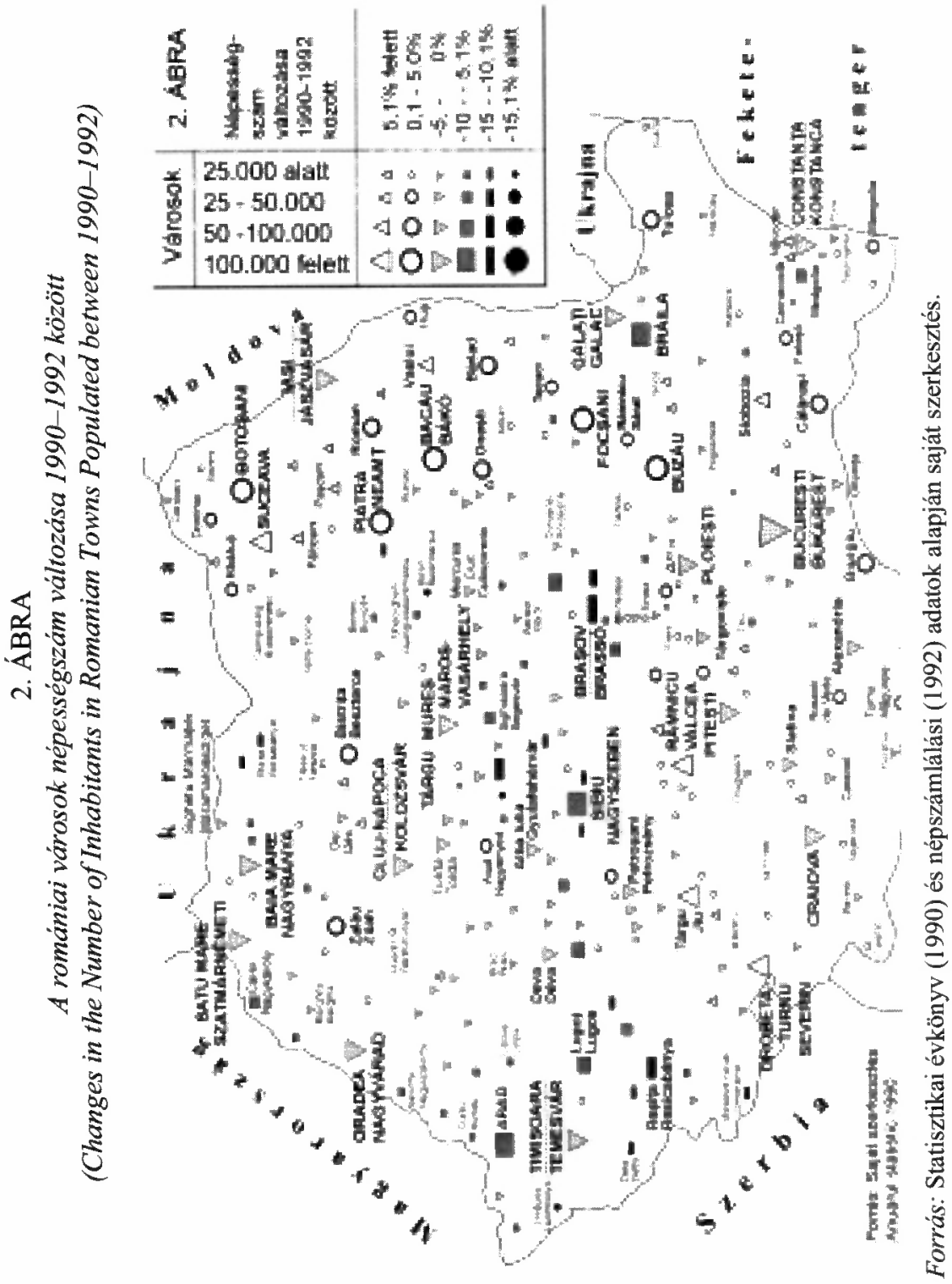




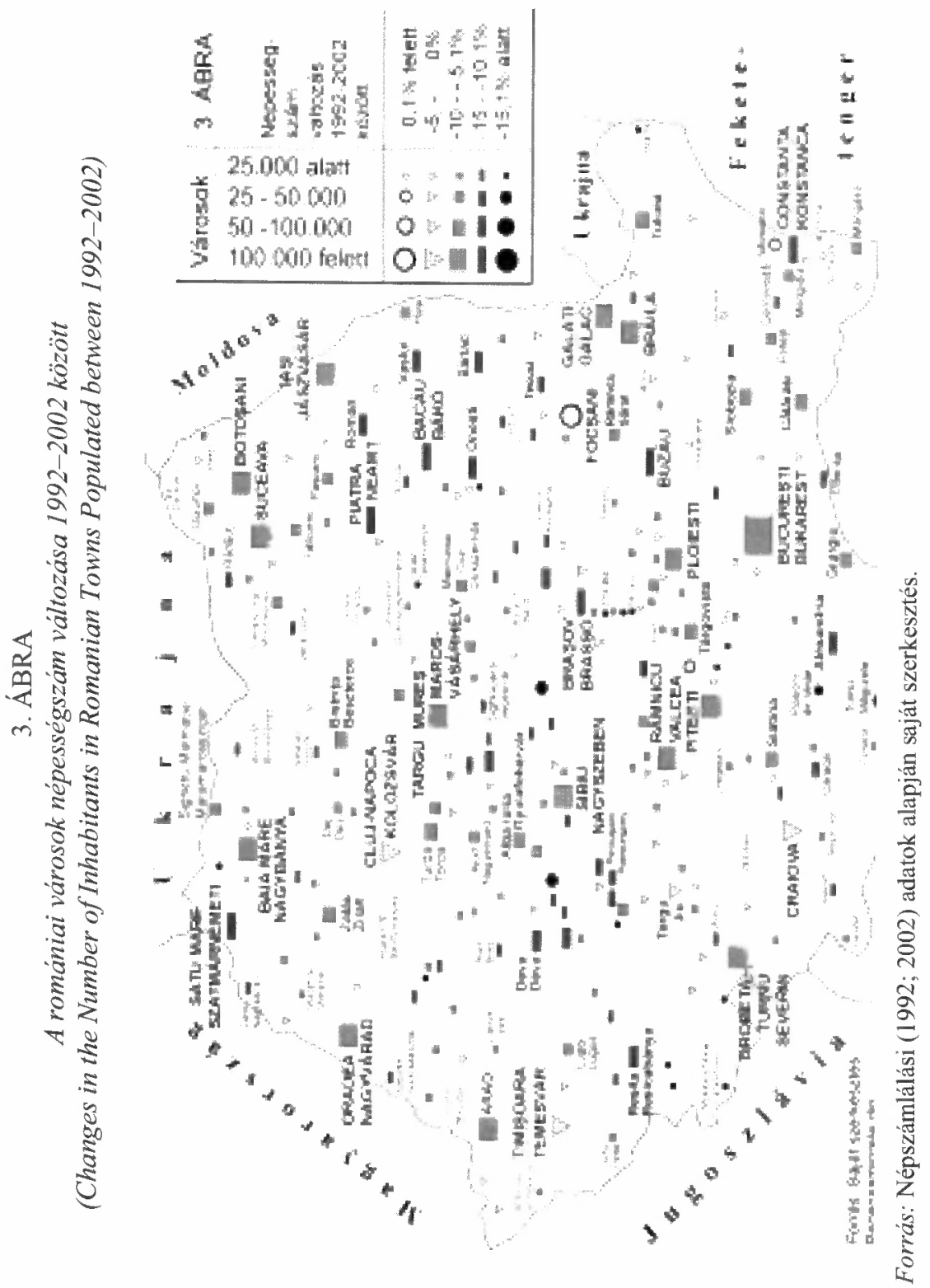


A gazdasági szerkezetátalakítás, a „megkésett”, de eredményes privatizáció, a hátrányos térségek felzárkóztatása és a múködő piacgazdaság kialakítása mellett a társadalmi problémák orvoslása (foglalkoztatottság növelése, szociális háló kiterjesztése, jogrend megerősitése, korrupció visszaszorítása, a családalapítás anyagi ösztönzése) javulást eredményezhet a negatív demográfiai folyamatok (születések csökkenése, elöregedés, kivándorlás) alakulásában. Ezt igazoljảk az utóbbi két év gazdasági eredményei, valamint a gyerekvállalást támogató törvény.

\section{Irodalom}

Anuarele statistice ale României. (1964; 1983; 1990; 1996; 2000; 2003) Bucureşti.

Dumitrache, L. (1995) Le comportement démographique récent de la population de Roumanie en contexte sud-est Européen. - Revue roumaine de géographie. 40. 117-126. o.

Elekes T. (2005) A városi népességszám változásai Romániában 1948-2002 között. - Pap N.-Végh A. (szerk.) A Kárpát-medence politikai földrajza. IV. Magyar Politikai Földrajzi Konferencia, Pécs. 95-103. o.

Geografia României II. (1984) Editura Academiei R.S.România, Bucureşti.

Gyenizse P. (2005) Helyi és helyzeti energiák hatása síksági települések fejlödésére. - Bugya T.Wilhelm Z. (szerk.) Tanulmányok Tóth Józsefnek. PTE, Földrajzi Intézet, Pécs. 256-272. o.

Horváth Gy. (1998) Európai regionális politika. Dialóg Campus, Budapest-Pécs.

Iaţu, C.-Muntele, I. (2002) La population de la Roumanie en pleine transition. Analele Universității „Al.I.Cuza" Iași. - Geografie. 2. 138-141. o.

Recensămintele populatiei şi aşezărilor din România (1948; 1966; 1977; 1992; 2002) București.

Nyárádi R.K. (2003) Erdély népesedéstörténete. ELTE-Központi Statisztikai Hivatal Levéltár, Budapest. Rechnitzer J. (1998) A területi stratégiák. Dialóg Campus, Budapest-Pécs.

Rudl J.(1998) Az új kisváros és a városi funkciók. - Földrajzi Értesitö. 1.31-41. o.

Tălângă, C. (1996) Evoluţia demografică a oraşelor României pe tipuri funcţionale. - Geographica Timisiensis. 5. 105-110. o.

Tóth J. (1981) A településhálózat és a környezet kölcsönhatásának néhány elméleti és gyakorlati kérdése. Földrajzi Ertesitö. 30. 268-292. o.

Tóth J.--Trócsányi A.--Elekes T. (2002) Térszerkezeti változások Erdélyben, a XIX. század végétöl napjainkig. - Pásztor C. (szerk.) Ahol a határ elválaszt. Trianon és következményei a Kárpát-medencében. Nagy Iván Történeti Kör -- Nógrád Megyei Levéltár, Balassagyarmat. 319-331, o.

Ungureanu, A.-lanoş, 1. (1996) Characteristic features of the urban system in Romania.- Revue roumaine de géographie. 40.

Varga E.Á. (1998). Erdély etnikai és felekezeti statisztikája. I-V. Teleki László Alapítvány, Pro Print könyvkiadó, Budapest-Csíkszereda. 